\title{
Corporate Social Commitment from Investors' Perspective: Evidences from Italian and UK Asset Management Companies
}

\author{
Mauro Sciarelli \\ Department of Economics, Management, Institutions \\ University of Naples "Federico II" \\ Naples, Italy \\ C. Giovanni Landi \\ Interdepartmental Research Centre L.U.P.T. \\ University of Naples Federico II, Naples, Italy \\ $\&$ \\ Department of Economics, Management, Institutions \\ University of Naples "Federico II" \\ Complesso Universitario Monte S. Angelo \\ Via Cinthia, 80126, Italy \\ Corresponding email: catellogiovanni.landi@unina.it \\ Lorenzo Turriziani \\ Department of Economics, Management, Institutions \\ University of Naples "Federico II" \\ Naples, Italy \\ Mario Tani \\ Department of Economics, Management, Institutions \\ University of Naples "Federico II" \\ Naples, Italy
}

\begin{abstract}
This work fits into a field of research dealing with the impact of Internet and Social Network as an effective social disclosure tool. We argue how investors' perception of company's self-presentation, financial prospects and social media communication can be associated to a successful performance of an Asset Management Company (AMC). In doing so, we carried out a stepwise analysis on 21 Italian and UK Asset Management Companies belonging to EUROSIF Panel. To accomplish this goal, we set up an experimental study enrolling university students of a Business Ethics course, aiming to understand how they evaluate an Asset Management Company's social commitment. Empirical findings denote the relationship between the social disclosure and the company's financial success, exploring which factors can affect social investors' perception and how they are able to associate a good corporate social commitment to a high corporate financial performance, once improved their knowledge about sustainable finance.
\end{abstract}

Keywords: social voluntary disclosure; corporate social responsibility; financial performance; socially responsible investment; social finance.

JEL Classifications: G41 $\cdot$ M14 $\cdot$ O16

\section{Introduction}

In the last three decades, the Internet has quickly become a new mass media. The increasing development of Internet and the subsequent rise of social networks such as Facebook and Twitter produced an important impact on every aspect of organizational and consumers life (O'Kane, Hargie \&Tourish, 2004) revolutionizing the way people and modern companies communicate (Capriotti \& Moreno, 2009; Springston, 2001). Indeed, these new digital tools of communication are still transforming the way people obtain information, communicate and engage in relationships with companies (Springston, 2001). 
Communication research about the organizational use of the Internet and the Social Networks has been mostly oriented towards the web sites characteristics and capabilities to disseminate information and to establish a stronger relationship between the companies and their stakeholders (Capriotti\& Moreno, 2007; Esrock \& Leichty, 1998,1999; Kent \& Taylor, 1998).

Furthermore, especially in the last decade, companies have been taking advantage fromthe web and social media to communicate their socially responsible activities and, according to Castelo Branco and Rodriguez (2008), the study of this media is essential to understand how much a company is sustainable.

In fact, they use the web to make the stakeholders more conscious about their socially responsible activities (Williams \& Pei, 1999) with additional details and interaction than those they could provide otherwise (Esrock \& Leichty, 2000).

Today the social media is among the best opportunities available to a socially responsible company for connecting with prospective consumers. At a higher level, in accordance with this assumption, recent studies have demonstrated social media's utility for, among other purposes, stakeholder dialogue (Bortree \& Seltzer, 2009; Waters et al., 2009), community building (Briones et al., 2011; Lovejoy \& Saxton, 2012) and advocacy work (Greenberg \& MacAulay, 2009; Guo \& Saxton, 2013). These studies collectively suggest social media allow organization to not only send and receive information but also connect and mobilize the public.

The evolution of the corporate social responsibility communication systems has also influenced the financial markets which, especially in recent years, have re-evaluated the role of ethics in investment decisions. This has strongly highlighted the need to communicate to the socially responsible investors the key intangible aspect related to social responsibility, shedding light on the sustainable aim and nature of socially responsible investments (SRIs) (Boulstridge \& Carrigan, 2000) as the long-run impacts their investment decisions can have on the society as a whole (Sparkes, 2001; McLachlan \& Gardner, 2004; Hockerts \& Moir, 2004). As regards the consequences of this change of perspective, the issue of coherence between the core values and the communication of these to different kinds of investors has become more and more relevant.

Nowadays, the asset management companies are trying to meet these needs screening specific companies or sectors, focusing investment in sustainable industries only, or implementing the broader diffusion of ethical investments in the form of socially responsible investments (Ziegler \& Schroeder, 2010; Bilbao-Terolet al., 2012). This derives from the awareness that a socially responsible investor makes financial decisions taking into account other non-financial aspects (Hockerts \& Moir, 2004; Margolis et al, 2009; Renneboog et al., 2008) using their personal value systems to set up their own investment criteria (Dobson, 1997; Sauer, 1997; Boatright, 2013).

To meet the investors' needs, the asset management company has to disclose clearly its value proposition, making the information content of the financial offer transparent, unambiguous and compliant with the value system of ethical investors. Accordingly, voluntary social disclosure, report and communication practices can help investors in investment decision, contributing to reducing the information asymmetry and aligning their complex values with that of the asset management company (Willis, 2003; Cox et al., 2004; Nilsson, 2008). The rapid adoption and development of a social-network-based communication progressively ensured that asset management companies can take advantage of another transmission channel to disclose the principles of CSR towards the relevant stakeholders. Hence, the purpose of this work is to try to understand if a well-knowledgeable ethical investor is able to associate an AMC's high financial performance with a high social commitment through the evaluation of its communication activity (e.g. mission, vision, history) and web and social media channels (e.g. Facebook and Twitter). This work starts primarily from the investigation about the relationships between the voluntary social disclosure and communication activities implemented by some ethical asset management companies (AMCs) through the social network channels - such as Facebook and Twitter.

\section{Prior literature}

\subsection{Company's self-presentation}

Recent studies have displayed an increasing interest for corporate social responsibility as it helps in enhancing the legitimacy of the company among its stakeholders (Handelman \& Arnold, 1999) besides developing a positive social responsibility image (Brown \& Dacin, 1997; Sen \& Bhattacharya, 2001). However, simply behaving in a socially responsible manner may not be sufficient to ensure stakeholders' acknowledgement of socially responsible commitment. Most research suggests that companies use their websites to highlight their CSR behaviors (Maignan \& Ralston, 2002) since they target a wide range of stakeholders (Esrock \& Leichty, 2000) deploying a well-defined CSR self-presentation. Therefore, corporate values, when directly expressed, are part of companies' mission statements, visions and historical overviews to be found in company profiles and websites (Nielsen \& Thomsen, 2009). 
Since companies' self-presentation contribute to model a common ground of identification between the stakeholders and the organization (Van Riel, 1992), it allows the company to establish a consistent communication strategy minimizing ethical risks. Thus, according to Basil and Erlandson (2008), acting as an uncertainty reducer, a positive relationship between corporate financial performance and company's self-presentation is expected. To understand if the investors' perception on ethical self-presentation is able to identify a well performing AMC, we define the following research hypothesis about the relationship between investors' perception and AMCs' self-presentation content:

Hypothesis 1: Investors' perception about ethics disclosed in AMCs' self-presentation affects positively the financial performance.

\subsection{Social disclosure on Web and social Media}

Social media usage among AMCs is increasing strongly (Parveen et al, 2015) as they play a very critical role in evolution, testing, diffusion and further modification of social innovations (Gupta et al., 2017). In this perspective, especially in the last decade, the Internet has created a fundamental shift in business and consumer behaviors. As a consequence, Web-based marketing entails using the Internet to provide information, to communicate and to conduct transactions in an increasingly complex environment (Cooke, 2017).

More specifically, the rise of social networks has granted new possibilities for organizations to engage their stakeholders by allowing them to send information out quickly and to receive real-time feedback. Hence, it can be argued that the social media innovation has favored the creation of a closer relationship between the firm and its customers using the web and its tools, considering the importance they have gained in the latest years (Della Corte et al., 2015). In particular, recent studies have demonstrated social media's utility for, among other purposes, stakeholder dialogue (Bortree\& Seltzer, 2009), community-building (Lovejoy \& Saxton, 2012), and advocacy work (Guo \& Saxton, 2013). According to Bortree and Seltzer (2009), social networking sites provide companies with a wide space to interact with key publics and to allow users to engage with one another on topics of mutual interest; this should provide the ideal conditions necessary for stimulating dialogic communication.

In short, nowadays online communication is considered to be a focal and strategic resource for the success of organizations beyond that a key information channel to which prospective investors increasingly turn for information on an organization's efficiency, effectiveness, performance and governance (Gordon et al., 2009). This short literature suggests that social media usage allows companies to not only send and receive information but also connect with and mobilize the public and - in the case of asset management companies - the potential investors. On the other hand, there is a growing use of such technologies, as through them, organizations provide their stakeholder a place to exchange opinions and thoughts, resulting in an excellent source of information to predict societal behavior (Schoen et al., 2013; Jungherr \& Jurgens, 2013; Kalampokis et al, 2013).

Hence, to analyze these aspects, we formulate the following research hypothesis:

Hypothesis 2: Investors' perception about centrality of ethics in Web and Social Media affects positively the financial performance.

Relative to the importance of social-based disclosure, Kent and Taylor (1998) introduced the subject of online relationship development to public relations, and many have advocated for organizations to implement strategic virtual communication strategies to cultivate relationships with key stakeholders. Saxton et al. (2014) state that Web-based organizational disclosure constitutes an important component of the AMCs information environment. In fact, not only does such disclosure help companies to relay their effectiveness and the ethical commitment to potential investors but, in the aggregate, social voluntary disclosure plays a key role in maintaining market efficiency and reducing information asymmetries. The usefulness of social networking site profiles often focuses on the information that is being distributed (Crespo, 2007). The most common forms of message dissemination include posting links to external news items about the organization or its causes; including press releases and campaign summaries on their social networking sites should also be encouraged to maximize the impact of their presence on social networking sites.

\subsection{Socially responsible investments and disclosure}

In the last twenty years, socially responsible investing (SRI), which encloses ethical values, environmental protection, improved social conditions and good governance, has increasingly attracted the interest of individual and private investors, as well as academics (Revelli \& Viviani, 2015). Hence, from a scientific point of view, most research in the last decade focused on SRI performances, seeking to understand whether this type of investment has financial costs beyond those associated with conventional investments, ad whether it affects positively the financial or market performance of an investment portfolio. Several empirical studies (Griffin \& Mahon, 1997; Roman et al, 1999; Margolis \& Walsh, 2003; Allouche \& Laroche, 2005) attempted to demonstrate a causal link between the effect of introducing non-financial aspects in the investment process and the financial performance of SRI funds. 
According to McCarthy et al. (2014), the adoption of a web-based disclosure alone does not guarantee a positive impact on the company's image and performance; other aspects such as the ethical commitment disclosed in SRIs financial prospects remain crucial to maintain interest and engagement in the AMC. Furthermore, such authors noted that one of the main concerns of the organizations is how social media content should be implemented, as an inappropriate and inconsistent social media communication activity could prejudice the organization's communication strategy (GallegoAlvarez et al., 2011).

Hence, in order to understand if the investors' perception on ethical financial products is able to identify a well performing ethical AMC, we define the subsequent research hypotheses:

Hypothesis 3: Investors' perception about ethics in AMCs' financial products affects positively the financial performance.

\subsection{The need of consistency}

By engaging in ethical activities, the AMCs, over the long run, can build a well-defined corporate image, strengthen stakeholder-company relationship and enhance stakeholder advocacy behaviors (Sen\& Bhattacharya, 2010).

The consistency through which a company engages in CSR can also impact on the corporate financial performance (Tang et al., 2012) as it helps in the construction of a good image that can be both a strategic asset (Dowling, 1993; Weigelt \& Camerer, 1988) and a source of sustainable competitive advantage (Aaker, 1996; Ghemawat, 1986; Hall, 1993). Moreover, a consistent corporation behavior indicates that the AMC involves itself with CSR activities in a systematic and regular way (Vermeulen \& Barkema, 2002). Indeed, a consistent approach helps company to better and more strategically outperform their CSR activities.

Moreover, a consistent socially responsible behavior builds stakeholder confidence in the AMCs' commitment to CSR. The consistency, for example, may improve investors commitment by supporting the belief that the ethical approach is a persistent goal for the AMC (Carmeli et al., 2007). In reverse, the inconsistency suggests that the AMC is behaving responsibly in an unplanned or opportunistic manner. It gives the impression that its CSR engagement is a mere response to the external pressures (Frooman, 1999).

Thus, in order to understand if the investors' perception on AMCs' consistency is able to identify a well performing ethical AMC, we define the subsequent research hypothesis:

Hypothesis 4: Relationship between investors' perception on AMCs' consistency and financial performance.

a. Investors' perception about consistency between self-presentation and ethical financial products affects positively the financial performance (Hp. $\left.4_{\mathrm{a}}\right)$.

b. Investors' perception about consistency between self-presentation and web and social-media based disclosure affects positively the financial performance (Hp. $\left.4_{\mathrm{b}}\right)$.

c. Investors' perception about consistency between ethical financial products and web and social-media based disclosure affects positively the financial performance (Hp. $\left.4_{\mathrm{c}}\right)$.

\section{Empirical study}

\subsection{Sample and Data}

We built up our sample filtering EUROSIF panel through different perspectives. First, we selected only AMCs located in Italy (21) and UK (54) given the partnership between Italian and English stock exchanges, identifying an overall amount of 75 AMCs. Our starting sample is made up of $28 \%$ by Italian AMCs and $72 \%$ by UK ones and then we screened these companies according to the following criteria:

1. AMCs addressing to private investors;

2. AMCs reporting their mission statement on the website;

3. AMCs deploying at least one socially responsible investment;

4. AMCs adopting both website and social media channels.

Thus, once applied our criteria to the AMCs population above, we carried out a sample composed by 21 AMCs promoting sustainability and active on Italian and UK financial markets. In particular, 6 are located in Italy, the remaining 15 in the UK. In doing so, we kept the same initial percentage of Italian (28\%) and UK (72\%) AMCs. In order to develop our valuation on their ethical commitment, we enrolled students attending a Business Ethics course, submitting them to a four-phase research experiment.

Data about ethical commitment of financial products were investigated on AMCs website and social media profiles. We tested how students' perception on social communication, considering its capability to lower information asymmetry, is able to identify a well performing AMC. 
This experimental research is meant to investigate the willingness to address capitals to impact investments, basing on social finance issues and awareness degree about responsible financial products. As mentioned previously, we framed our analysis into four phases:

- Phase 1: each companies' self-presentation was evaluated through three perspectives that are mission information, vision statement and history description.

- Phase 2: AMCs financial portfolio was diagnosed aiming at identifying funds' characteristics featuring the ethical funds, impact investments, social venturing or social crowd funding campaign.

- Phase 3: companies communication releases were collected from web and social media channels, considering oneyear timeframe (2017).

- Phase 4: students at the end of the study rated the consistency between AMCs ethical commitment and their financial portfolios, which is also an overall perception about eventual social fishing phenomena in fundraising.

In order to fulfill each phase, we collected data and information from Key Investor Information Documents (KIIDs), prospects and overview of AMCs disclosed on their website.

In addition, we checked on main social network Facebook and Twitter whether AMCs have a corporate profile which helps them to make deeper and more persuasive their marketing strategy, alongside classical web news spreading companies' compliance to CSR and sustainability.

Finally, we get AMCs' financial health indicators on Orbis platform, a data-warehouse of comprehensive information on European companies, supported by Bureau Van Dijk.

Table 1. Variables

\begin{tabular}{|c|c|c|}
\hline Variables & Description & Measure \\
\hline \multicolumn{3}{|l|}{ Dependent Variables } \\
\hline$\triangle \mathrm{ROA}$ & $\begin{array}{l}\text { EBIT/Assets meant to express economic performance } \\
\text { expressed in terms of one-year variation rate }\end{array}$ & Ratio \\
\hline$\triangle \mathrm{ROE}$ & $\begin{array}{l}\text { Net Profit/Equity investment expressed in terms of one-year } \\
\text { variation rate }\end{array}$ & Ratio \\
\hline$\Delta$ ASS_TURN & $\begin{array}{l}\text { Net Sales Revenue/Average Total Assets meant to express } \\
\text { assets' capability in generating sales revenue or sales income } \\
\text { to the company expressed in terms of one-year variation rate }\end{array}$ & Ratio \\
\hline \multicolumn{3}{|l|}{ Independent Variables } \\
\hline \multicolumn{3}{|c|}{ Hp 1 - Self-Presentation } \\
\hline SP_ETH (Hp1) & Centrality of Ethics in company self-presentation & 5-likert scale \\
\hline \multicolumn{3}{|l|}{$\begin{array}{c}\text { Hp } 2 \text { - Web and Social } \\
\text { Media }\end{array}$} \\
\hline WSM_ETH (Hp2) & Centrality of Ethics in Web and Social Media & 5-likert scale \\
\hline \multicolumn{3}{|c|}{ Hp 3 - Financial products } \\
\hline FP_ETH (Hp3) & Centrality of Ethics in AMC's financial products' supply & 5-likert scale \\
\hline \multicolumn{3}{|l|}{ Hp 4 - Consistency } \\
\hline SP-FP $\left(H p 4_{a}\right)$ & $\begin{array}{l}\text { Consistency level between self-presentation and financial } \\
\text { products supply }\end{array}$ & 5-likert scale \\
\hline SP-WSM $\left(H p 4_{b}\right)$ & $\begin{array}{l}\text { Consistency level between self-presentation and web and } \\
\text { social-media based disclosure }\end{array}$ & 5-likert scale \\
\hline FP-WSM $\left(H p 4_{c}\right)$ & $\begin{array}{l}\text { Consistency level between financial products supply and web } \\
\text { and social-media based disclosure }\end{array}$ & 5-likert scale \\
\hline
\end{tabular}

\subsection{Dependent and Independent variables}

There are several indicators able to assess companies' financial health in performance terms, hence in doing so we adopted two perspectives ranging from previous year to current year: a) a financial-based measurement using asset turnover ratio (Timbate \& Kyu Park, 2018); b) a double accounting-based measurement expressed by Return on Asset (ROA) ratio and Return on Equity (ROE) ratio as a profitability proxy of an AMC. 
Concerning with research measurements applied to each phase, we arranged a sentence analysis assessing through a dichotomous variable the presence of some items underlying companies' self-presentation. On this ground, we evaluated AMCs' ethical commitment in presenting themselves following a content approach (Hp.1 and Hp.2) (GalvezRodriguez et al., 2016) upon scope in mission statement, ESG paradigm application, CSR citation, sustainability concept, stakeholder engagement and whether companies adopted an ethical approach among Kantian,utilitarian, Rawlsian and virtue ethics perspectives.

Regarding to social purposes of financial products issued by companies (Hp.4), we analyzed sentences withinKIID and fund prospects able to describe the methodology that AMCs deployed in building a socially responsible portfolio through the lenses of heterogeneity of socially responsible funds, the "positive/best in class/negative" screening method followed in selecting bonds composition of ethical funds, the ESG guidelines of impact investments and shareholder activism in investment decision making.

In order to estimate above items in financial products description, we carried out again a dichotomous approach. Both for self-presentation and financial products, students expressed their perception using a five-Likert scale about AMCs stakeholder engagement, the role of sustainability and the centrality of ethics.

In third phase, companies' web and social media communication policy were measured basing on their web releases, including ESG disclosure, the social and financial performance comparison (Hp.3), CSR engagement and the same ethical approaches of self-presentation (Saxton et al., 2014). Even in this case we used a five-Likert method to express whether and how students enrolled in this experiment perceived AMCs social disclosure, ESG depth communication and centrality of ethics.

Once accomplished our three phases, we synthesized the consistency among phases for understanding where companies deploying a socially responsible marketing strategy in fundraising met investors' ethical expectations along the entire value chain (Hp.4). Therefore, students formulated an overall perception evaluation about coherence between: self-presentation and financial products; financial products and web and social media communication and finally self-presentation and web and social media communication.

Table 2. Correlation Matrix

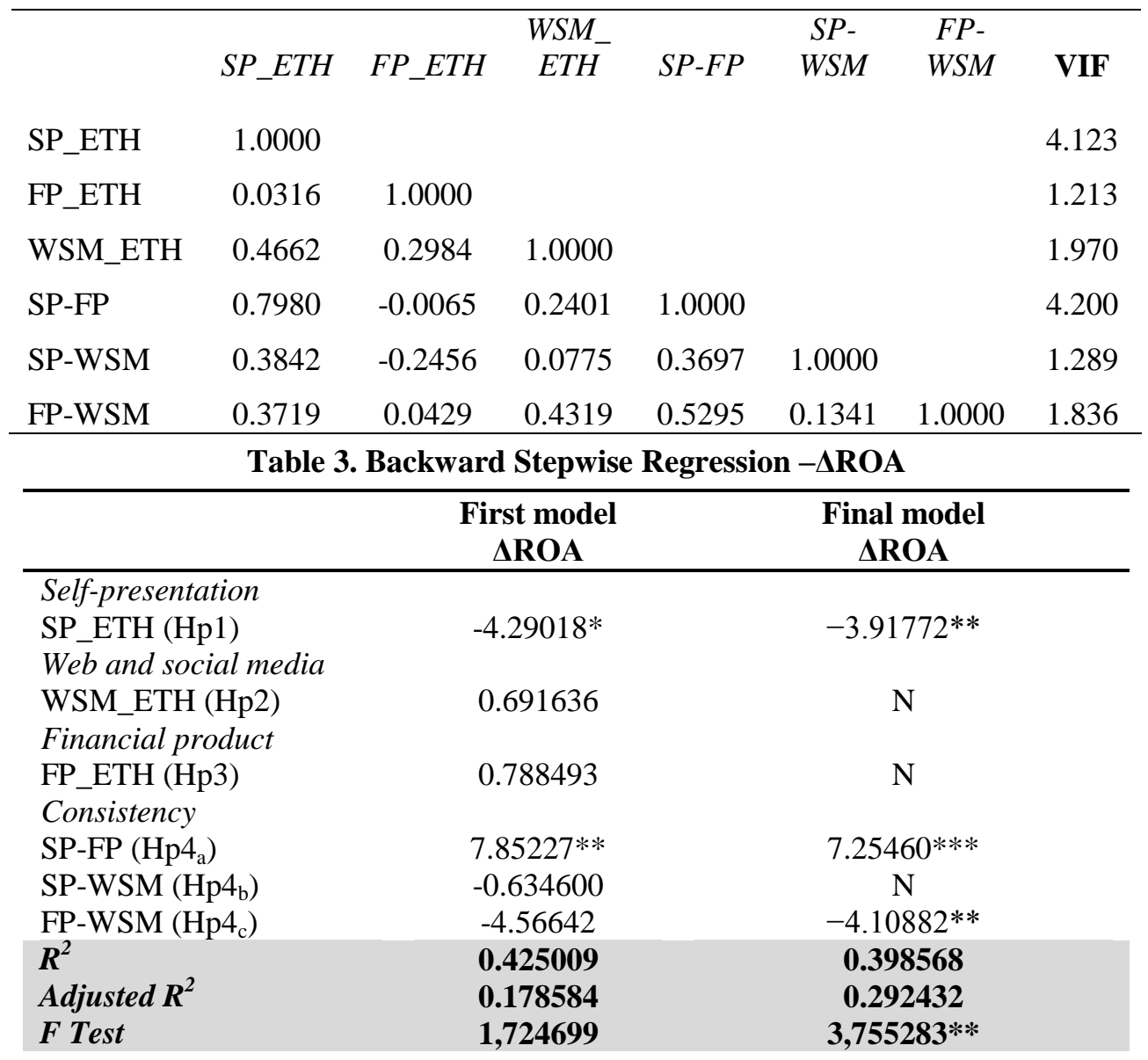




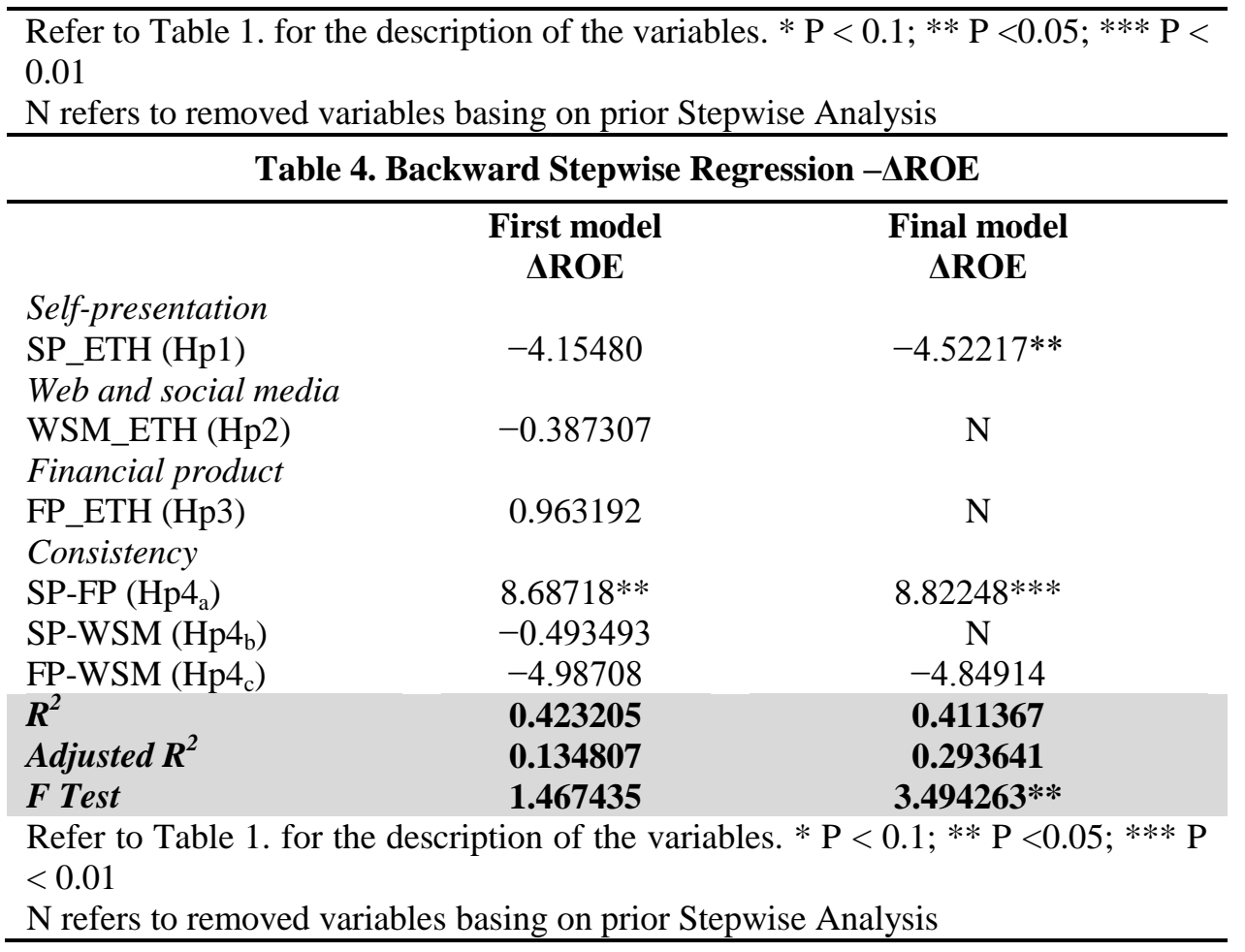

Table 5. Backward Stepwise Regression - $\triangle$ ASS_TURN

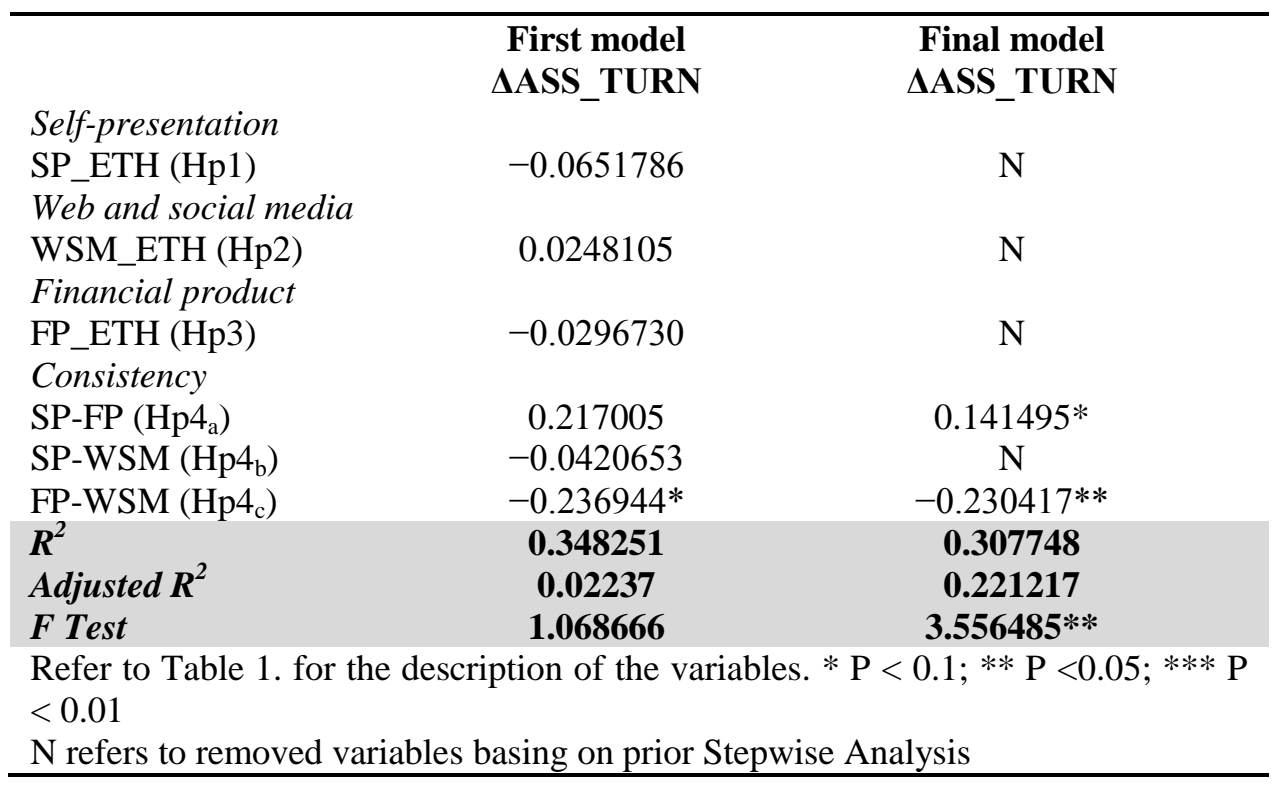

\subsection{Analysis and results}

In fiscal year 2017, we applied a backward stepwise analysis (Diez et al., 2012) to our research design using an OLS statistical approach. Backward elimination begins from the full model which takes into consideration all potential predictor variables. We improve the adjusted $\mathrm{R}^{2}$ removing variables from the first model through a stepwise approach. The meaning underlying each elimination step is to leave out the variables whichdo not lead us to better adjusted $\mathrm{R}^{2}$ values. We tested the association between investors' perception about AMCs' self-presentation, ethical financial products, web and media communication strategy and their financial performance for each dependent measure, following a regression model based on these analytical patterns:

$\Delta \mathbf{R O A}_{\mathrm{i}}=\beta_{0}+\beta_{1}$ SP_ETH $_{\mathrm{i}}+\beta_{2} \mathrm{WSM}_{-} \mathrm{ETH}_{\mathrm{i}}+\beta_{3} \mathrm{FP}_{-} \mathrm{ETH}_{\mathrm{i}}+\beta_{4}$ SP-FP $_{\mathrm{i}}+\beta_{5}$ SP-WSM $_{\mathrm{i}}+\beta_{6} \mathrm{FP}_{-} \mathrm{WSM}_{\mathrm{i}}+\varepsilon_{\mathrm{i}}$

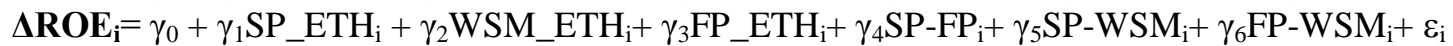

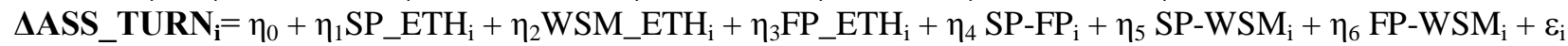


Concerning with our research hypotheses, we did not find significant findings in everyone. Hence, what clearly results about Hp.1 from tables 3 and 4, is that investors' perception related to a corporate ethical practice (SP_ETH) disclosed through Web Self-presentation is negatively associated to a high AMCs' profitability expressed by ROA and ROE ( $p_{\mathrm{SP}-}$ $\mathrm{ETH}<0,05)$.

The second significant outcome concerns with Hp. $4_{\mathrm{a}}$. As shown in tables 3, 4 and 5, investors' perception deriving from a high consistency between AMCs' self-presentation and ethical financial products is positively associated to a growing AMCs' financial performance in all three models $\left(\Delta \mathrm{ROA}: p_{\mathrm{SP}-\mathrm{FP}}<0,01 ; \Delta \mathrm{ROE}: p_{\mathrm{SP}-\mathrm{FP}}<0,01 ; \Delta \mathrm{ASS} \_\mathrm{TURN}: p_{\mathrm{SP}-}\right.$ FP $<0,1)$. Finally and regarding to Hp. $4_{c}$, investors' perception coming from a high degree of consistency between AMCs' ethical financial products and web and social media communication corresponds to a lower AMCs' financial performance $\left(\Delta \mathrm{ROA}: p_{\mathrm{FP}-\mathrm{WSM}}<0,05 ; \Delta \mathrm{ASS} \_\mathrm{TURN}\right.$ : $\left.p_{\mathrm{FP}-\mathrm{WSM}}<0,05\right)$.

Moreover, we employed our data to make a correlation study, highlighting the relationship among all independent variables collected in empirical research. We checked for multicollinearity condition through the Variance Inflation Factor (VIF), whose values are lower than 10 as reported in Table 2.

\section{Discussion and conclusion}

This research focuses on the relationship between voluntary disclosure of social practices deployed by a set of ethical AMCs located in Italy and UK and their financial performance, given the increasing adoption of social networks for non-financial disclosure. On this ground, we selected those AMCs that are actively involved in promoting and selling ethical financial products to retail investors.

Our empirical results show different scenarios ahead an ethical AMC. Primarily, a group of potential investors addicted to ethics in finance, would be able to identify the AMCs with greater financial health basing upon the consistency underlying their socially responsible mission and the portfolio of ethical financial products they issue on the reference markets. This indicates that a student who attends a course of business ethics frames with less skepticism the positive association between ethical financial products and the AMC business performance. Therefore, a greater awareness on how business ethics can create economic value implies an improvement in the investments selection process both on an ethical and economic perspective, once verified the consistency between the mission and the financial portfolio of an $\operatorname{AMC}\left(\mathrm{Hp}_{\mathrm{a}}\right)$.

However, where AMC's financial products leverage on web-based promotional tools (e.g. Twitter; Facebook; WebNews), a high degree of consistency between financial products and a reliable web-marketing strategy corresponds to a serious bias in decision making $\left(\mathrm{Hp} 4_{c}\right)$. Hence, our research analysis shows a misalignment between a potential investor and an AMC social commitment, since the consistency between financial products and web-marketing strategy is not rewarded by an equally high economic return. This could mean that a good promotion campaign of ethical financial products, prior to an effective impact disclosure, deviates the decision maker from an efficient capital allocation.

In addition, whether AMC discloses an ethical commitment in its web self-presentation, this can bias an investment decision maker (student in our case) in allocating efficiently resources, since investor considers ethics standing alone not able to lower information asymmetry which leads her/him to select a high performing AMC (Hp.1).

Our study has some limits regarding to the sample size: hence, future studies could bring this analysis to a broader level, involving other business courses taught in other countries. In addition, the evaluator group belongs to a single study course, so its members could not be fully aware about ethical finance dynamics. Besides, about the perception evaluation, a Likert scale - ranging from 0 to 5 - could be reductive in terms of granularity. A future research study could increase empirical findings exploring students' perception about ESG and corporate social performance disclosure through web and social media communications, and their capability to recognize a well-performing AMC from stakeholder engagement prospective underlying its financial products. This in turn would point out whether social commitment really works on investment markets instead of denoting a social washing corporate practice.

Our practical implications of the study suggest that a potential ethical investor should focus on the real consistency outstanding self-presentation carried out by AMCs and their financial products, rather than the promotional content these entities disclose on web self-presentation. Besides the implications above, the investors' perception about AMCs financial health seems to decrease whether AMCs promote their ethical financial products through web-marketing tools, leading them to not trust these socially responsible investments. 


\section{References}

Aaker, D. A. (1996). Measuring brand equity across products and markets. California management review, 38(3), 102.

Allouche, J., \&Laroche, P. (2005). A meta-analytical investigation of the relationship between corporate social and financial performance.Revue de gestion des ressourceshumaines, (57), 18.

Basil, D. Z., \&Erlandson, J. (2008). Corporate social responsibility website representations: A longitudinal study of internal and external self-presentations. Journal of Marketing Communications, 14(2), 125-137.

Bhattacharya, C. B., \&Sen, S. (2004). Doing better at doing good: When, why, and how consumers respond to corporate social initiatives. California management review, 47(1), 9-24.

Bilbao-Terol, A., Arenas-Parra, M., \&Cañal-Fernández, V. (2012).Selection of socially responsible portfolios using goal programming and fuzzy technology.Information Sciences, 189, 110-125.

Boatright, J. R. (2013). Ethics in finance.John Wiley \& Sons.

Bortree, D. S., \& Seltzer, T. (2009). Dialogic strategies and outcomes: An analysis of environmental advocacy groups' Facebook profiles. Public Relations Review, 35(3), 317-319.

Boulstridge, E., \&Carrigan, M. (2000). Doconsumers really care about corporate responsibility? Highlighting the attitude - behaviour gap. Journal of communication management, 4(4), 355-368.

Branco, M. C., \&Rodrigues, L. L. (2008).Factors influencing social responsibility disclosure by Portuguese companies.Journal of business Ethics, 83(4), 685-701.

Briones, R. L., Kuch, B., Liu, B. F., \& Jin, Y. (2011). Keeping up with the digital age: How the American Red Cross uses social media to build relationships. Public relations review, 37(1), 37-43.

Brown, T. J., \&Dacin, P. A. (1997). The company and the product: Corporate associations and consumer product responses. The Journal of Marketing, 68-84.

Capriotti, P., \& Moreno, A. (2007). Corporate citizenship and public relations: The importance and interactivity of social responsibility issues on corporate websites. Public relations review, 33(1), 84-91.

Capriotti, P. \& Moreno, A., (2009). Communicating CSR, citizenship and sustainability on the web. Journal of Communication Management, 13(2), 157-175.

Carmeli, A., Gilat, G., \& Waldman, D. A. (2007). The role of perceived organizational performance in organizational identification, adjustment and job performance.Journal of Management Studies, 44(6), 972-992.

Cooke, P. N. (Ed.). (2017). Localities: the changing face of urban Britain. Routledge.

Cox, P., Brammer, S., \& Millington, A. (2004).An empirical examination of institutional investor preferences for corporate social performance.Journal of Business Ethics, 52(1), 27-43.

Crespo, R. (2007). Virtual community health promotion.Preventingchronicdisease, 4(3).

Della Corte, V., Iavazzi, A., \& D'Andrea, C. (2015). Customer involvement through social media: the cases of some telecommunication firms. Journal of Open Innovation: Technology, Market, and Complexity, 1(1), 10.

Diez, D. M., Barr, C. D., \&Cetinkaya-Rundel, M. (2012). OpenIntro statistics (Vol. 12). CreateSpace independent publishing platform.

Dobson, J. (1997). Ethics in finance II. Financial Analysts Journal, 53(1), 15-25.

Dowling, G. R. (1993). Developing your company image into a corporate asset. Long range planning, 26(2), 101-109.

Du, S., Bhattacharya, C. B., \&Sen, S. (2010). Maximizing business returns to corporate social responsibility (CSR): The role of CSR communication. International Journal of Management Reviews, 12(1), 8-19.

Dubbink, W., Graafland, J., \& Van Liedekerke, L. (2008). CSR, transparency and the role of intermediate organisations.Journal of Business Ethics, 82(2), 391-406.

Esrock, S. L., \&Leichty, G. B. (1998). Social responsibility and corporate web pages: Self-presentation or agendasetting?. Public relations review, 24(3), 305-319.

Esrock, S. L., \&Leichty, G. B. (1999). Corporate World Wide Web pages: Serving the news media and other publics. Journalism \& Mass Communication Quarterly, 76(3), 456-467.

Esrock, S. L., \&Leichty, G. B. (2000). Organization of corporate web pages: Publics and functions. Public Relations Review, 26(3), 327-344.

Frooman, J. (1999). Stakeholder influence strategies.Academy of management review, 24(2), 191-205.

Gallego-Alvarez, I., Manuel Prado-Lorenzo, J., \& García-Sánchez, I. M. (2011). Corporate social responsibility and innovation: a resource-based theory. Management Decision, 49(10), 1709-1727.

Gálvez-Rodríguez, M. D. M., Caba-Pérez, C., \&López-Godoy, M. (2016).Drivers of Twitter as a strategic communication tool for non-profit organizations. Internet Research, 26(5), 1052-1071.

Ghemawat, P. (1986). Sustainable advantage. Harvard business review, 64(5), 53-58.

Gordon, T. P., Knock, C. L., \& Neely, D. G. (2009). The role of rating agencies in the market for charitable contributions: An empirical test. Journal of accounting and public policy, 28(6), 469-484. 
Greenberg, J., \& MacAulay, M. (2009). NPO 2.0? Exploring the web presence of environmental nonprofit organizations in Canada. Global Media Journal, 2(1), 63.

Griffin, J. J., \& Mahon, J. F. (1997). The corporate social performance and corporate financial performance debate: Twenty-five years of incomparable research. Business \& society, 36(1), 5-31.

Guo, C., \& Saxton, G. D. (2014). Tweeting social change: How social media are changing nonprofit advocacy. Nonprofit and Voluntary Sector Quarterly, 43(1), 57-79.

Gupta, A., Dey, A., \& Singh, G. (2017). Connecting corporations and communities: Towards a theory of social inclusive open innovation. Journal of Open Innovation: Technology, Market, and Complexity, 3(1), 17.

Hall, R. (1993). A framework linking intangible resources and capabilities to sustainable competitive advantage.Strategic management journal, 14(8), 607-618.

Handelman, J. M., \& Arnold, S. J. (1999). The role of marketing actions with a social dimension: Appeals to the institutional environment. the Journal of Marketing, 33-48.

Hockerts, K., \&Moir, L. (2004). Communicating corporate responsibility to investors: The changing role of the investor relations function. Journal of Business Ethics, 52(1), 85-98.

Jungherr, A., \&Jürgens, P. (2013). Forecasting the pulse: how deviations from regular patterns in online data can identify offline phenomena. Internet Research, 23(5), 589-607.

Kalampokis, E., Tambouris, E., \&Tarabanis, K. (2013). Understanding the predictive power of social media. Internet Research, 23(5), 544-559.

Kent, M. L., \& Taylor, M. (1998). Building dialogic relationships through the World Wide Web. Public relations review, 24(3), 321-334.

Lovejoy, K., \& Saxton, G. D. (2012). Information, community, and action: How nonprofit organizations use social media. Journal of Computer-Mediated Communication, 17(3), 337-353.

Maignan, I., \& Ralston, D. A. (2002). Corporate social responsibility in Europe and the US: Insights from businesses' self-presentations. Journal of International Business Studies, 33(3), 497-514.

Margolis, J. D., \& Walsh, J. P. (2003). Misery loves companies: Rethinking social initiatives by business. Administrative science quarterly, 48(2), 268-305.

Margolis, J. D., Elfenbein, H. A., \& Walsh, J. P. (2009). Does it pay to be good... and does it matter? A meta-analysis of the relationship between corporate social and financial performance.

McCarthy, J., Rowley, J., Jane Ashworth, C., \&Pioch, E. (2014). Managing brand presence through social media: the case of UK football clubs. Internet Research, 24(2), 181-204.

McLachlan, J., \& Gardner, J. (2004). A comparison of socially responsible and conventional investors.Journal of Business Ethics, 52(1), 11-25.

Nielsen, A. E., \& Thomsen, C. (2009). Investigating CSR communication in SMEs: a case study among Danish middle managers. Business ethics: A European review, 18(1), 83-93.

Nilsson, J. (2008). Investment with a conscience: Examining the impact of pro-social attitudes and perceived financial performance on socially responsible investment behavior. Journal of Business Ethics, 83(2), 307-325.

O'Kane, P., Hargie, O., \&Tourish, D. (2004). Communication without frontiers. Key Issues in Organisational Communication, Routledge, London, 74-95.

Parveen, F., Jaafar, N. I., \&Ainin, S. (2015). Social media usage and organizational performance: Reflections of Malaysian social media managers. Telematics and Informatics, 32(1), 67-78.

Renneboog, L., Ter Horst, J., \& Zhang, C. (2008). Socially responsible investments: Institutional aspects, performance, and investor behavior. Journal of Banking \& Finance, 32(9), 1723-1742.

Revelli, C., \&Viviani, J. L. (2015). Financial performance of socially responsible investing (SRI): what have we learned? A meta-analysis. Business Ethics: A European Review, 24(2), 158-185.

Roman, R. M., Hayibor, S., \&Agle, B. R. (1999). The relationship between social and financial performance: Repainting a portrait. Business \& Society, 38(1), 109-125.

Sauer, D. A. (1997). The impact of social-responsibility screens on investment performance: Evidence from the Domini 400 Social Index and Domini Equity Mutual Fund. Review of Financial Economics, 6(2), 137-149.

Saxton, G. D., Neely, D. G., \&Guo, C. (2014). Web disclosure and the market for charitable contributions.Journal of Accounting and Public Policy, 33(2), 127-144.

Schoen, H., Gayo-Avello, D., Takis Metaxas, P., Mustafaraj, E., Strohmaier, M., \&Gloor, P. (2013).The power of prediction with social media.Internet Research, 23(5), 528-543.

Sparkes, R. (2001). Ethical investment: whose ethics, which investment?. Business Ethics: A European Review, 10(3), 194-205.

Springston, J. K. (2001). Public relations and new media technology: The impact of the Internet. Handbook of public relations, 603-614. 
Tang, Z., Hull, C. E., \& Rothenberg, S. (2012). How corporate social responsibility engagement strategy moderates the CSR-financial performance relationship. Journal of Management Studies, 49(7), 1274-1303.

Timbate, L., \& Park, C. K. (2018). CSR Performance, Financial Reporting, and Investors' Perception on Financial Reporting. Sustainability, 10(2), 522.

Van Riel, C. B. (1992). Principles of corporate communication. Prentice Hall.

Vermeulen, F., \&Barkema, H. (2002). Pace, rhythm, and scope: Process dependence in building a profitable multinational corporation. Strategic Management Journal, 23(7), 637-653.

Waters, R. D., Burnett, E., Lamm, A., \& Lucas, J. (2009). Engaging stakeholders through social networking: How nonprofit organizations are using Facebook. Public relations review, 35(2), 102-106.

Weigelt, K., \&Camerer, C. (1988). Reputation and corporate strategy: A review of recent theory and applications. Strategic management journal, 9(5), 443-454.

Williams, S. M., \& Pei, C. A. H. W. (1999). Corporate social disclosures by listed companies on their web sites: An international comparison. The International Journal of Accounting, 34(3), 389-419.

Ziegler, A., \&Schröder, M. (2010). What determines the inclusion in a sustainability stock index?: A panel data analysis for european firms. Ecological Economics, 69(4), 848-856. 